\title{
Body Image and Self-Esteem as Predictors of Indecent Dressing among Female Undergraduates in Universities in Anambra State, Nigeria
}

\author{
Elizabeth Ifeoma Anierobi, Chukwuemeka Nelson Etodike, Azuka Eluemuno, and Mary Nneka Nwikpo
}

\begin{abstract}
Despite the social threats and devastating consequences of indecent dressing on students, female undergraduates in Universities in Anambra State still indulge in it without cognizance of acceptable dressing ethics. In view of the dangers it portends, this study examined body image and self-esteem as culpable factors which predispose undergraduates to indecent dressing. Using correlation research design for the study, two research questions were posed whereas two hypotheses were tested at 0.05 level of significance. In the method section, we utilized multi-stage sampling technique to manage the 21,532 population female undergraduates in Universities in Anambra State. After sample reduction, a sample of 1,250 female undergraduate students was selected from two public universities in Anambra State. During the survey, opinion of the female undergraduates was elicited using Body Image and Self-Esteem Questionnaire (BISEQ) and Indecent Dressing Scale (IDS). Reliability of both instruments was determined using Cronbach Alpha method and alpha coefficients of 0.71 and 0.69 were obtained for BISEQ and IDS respectively. The data were analyzed using Pearson Product Moment Correlation for answering research questions and Regression statistical analysis for testing the hypotheses. The results indicated that there is a positive and significant relationship between body image and indecent dressing among undergraduate students in universities in Anambra State. There is a positive and significant relationship between self-esteem and indecent dressing among undergraduate students in universities in Anambra State. Based on the findings of the study, it was recommended among others that policies should be made and implemented against indecent dressing in universities.
\end{abstract}

Key words - Body Image, Indecent Dressing, Self-Esteem, Undergraduates.

\section{INTRODUCTION}

Dressing is an important part of people's culture and lifestyle. Apparently, different cultures have their peculiar style of dressing which parents imbibe in their children from home which is the child's first point of socialization [1]. Whatever characterizes dress pattern in a particular culture might not be entirely accepted or rejected in another culture. Basically, in most cultures especially in Anambra State, Nigeria, through observations, one can assert that any dressing pattern which makes one appear responsible and

Published on August 21, 2021.

Elizabeth Ifeoma Anierobi, PhD, Department of Educational Foundations, Nnamdi Azikiwe University, Awka, Nigeria.

(e-mail: ei.anierobi@unizik.edu.ng)

C. E. Etodike, PhD, Heritage Research Gallery \& Mgt Consult Awka,

Nigeria.

(e-mail: nelsonetodike@gmail.com) decent is accepted whether the attire is of their cultural milieu or not. This implies that the culture within Anambra State promotes decency in dressing. Decent dressing is the one that covers one's nudity and other critical parts of one's body [2]. There is a saying that one is addressed as one dressed. In Anambra State, for instance, anyone that is dressed in clothes that are suggestive or those which reveals one's private parts are seen and addressed as an irresponsible fellow in the society and in the university campus, an invitation for sexual harassment [3].Bearing this in mind, every person including the students in Anambra State are expected to pay close attention to their dressing pattern.

However, the advent of westernization and technology era heralded reorientation in every society, Anambra State inclusive. This reorientation has giving rise to youths who seem to have lost their cultural identity and no longer pay quality attention to upholding the dressing values and norms of their societies [4]. No wonder, most of the youths in Anambra State, in a bid to appear western, dress to slay, and in their exuberant slang "dress to kill", against their cultural dressing ethics. One can easily spot this pattern of dressing to slay in most public places in Anamabra State such as at the malls, markets, parks, streets, churches, and tertiary institutions, against the cultural general acceptable dressing pattern. By implication, when the dressing pattern acceptable within the ambiance of the culture in Anambra State is defeated through the type of dress one is putting one, such dressing is always termed indecent.

Indecent dressing is one of the social threats in our contemporary society especially in universities in Nigeria. It is an undeniable fact that most students in Nigeria especially in Anambra State engage in indecent dressing [5], [3]. Operationally, indecent dressing involves lewd and inappropriate dressing styles that unnecessarily expose an individual's body in a suggestive manner. Such dressing styles and pattern expose one's critical and sensitive body parts such as the buttocks, naval area, breast cleavages, armpits, laps, and other body curves in a provocative manner and aids seduction to the opposite sex [6]. Indecent dressing seems to have become the dressing norm of students in universities in Nigeria not just Anambra State which one of the consequences of institutional corruption [7] with obvious implications. Most students that dress indecently is as a result

A. Eluemuno, PhD, Department of Educational Foundations, Nnamdi Azikiwe University, Awka, Nigeria

(e-mail: a.eluemuno@unizik.edu.ng)

M. N. Nwikpo, PhD, Department of Educational Foundations, Nnamdi Azikiwe University, Awka, Nigeria

(e-mail: mn.nwikpo@unizik.edu.ng) 
of low self-esteem [8] and social maladjustment [9] due to peer pressure.

Regrettably, most students in universities dress provocatively to school with dressing styles that openly reveal their vital body parts. Some of them put on such dresses as miniskirts that make sitting for them practically impossible without exposing their laps; very tight leggings and other 'hot' gowns that expose their body contours, tops that reveal their naval area and breast cleavages, spaghetti hand tops, show chest, show tummy, body hugs, show back, off shoulder, tube, net tops, sagging trousers, bum shorts [10], [11]. In Anambra State, all these types of dress are categorized as indecent dressing which if a student must wear, should only be in the privacy of their apartment or to night parties but never to school. Adebayo In [12] rightly pointed out that no dress would be considered indecent if worn in the privacy of one's apartment. However, it became worrisome that most university students practically appear in their various schools and lecture classes indecently dressed without taking cognizance that decent dressing earns them respect from their lecturers and equally guards their poise [13].

Some studies have pointed out some of the factors that had led students into indecent dressing. For instance, some school of thought blamed indecent dressing on influences from peers and celebrities, the society, social and mass media, westernization, the quest to be noticed and inferiority complex [14], [6], [15]. Others pointed out that indecent dressing has negative impacts and consequences such as poor academic performance, sexual harassment [3], causes distraction and seduction to male lecturers [13], [10], [16]. True to the negative consequences of indecent dressing, students have negative perception over the immoral dressing pattern [14]. Despite the consequences of and students' negative perception of indecent dressing, students in universities in Anambra State still engage in it with reckless abandon. This raises the curiosity of the researchers to explore other factors that could predict indecent dressing among undergraduates in universities in Anambra State. As a matter of fact, external appearances seem to be one of the priorities of undergraduate students in universities. For instance, it is common to observe that students usually shop for wears that will appeal to their physical appearance and also create in them an impression of "having arrived" as university students to their observers. This no doubt, underscores body image as a seeming factor that could predict indecent dressing among the students.

Body image refers to the perception of students on the attractiveness or not of their physical appearance. It is both mental depiction and social interpretation of one's physical appearance [17]. Every individual is created to be unique with physical structures and attributes genetically inherited from one's parents [18]. As people pass through stages of development, nature and nurture play out to shape one's physical attributes and endowment making some seems to appear more appealing than others. Beauty lies in the eyes of the beholder, and this seems to account for why some people engage in dieting, make-ups and exercise to appear more appealing to one's eyes. Thus, body image, a subjective evaluation of one's physical appearance [10] has become an issue of concern growing rapidly throughout Nigeria and various areas of the world.

This concern is true given the fact that marketers throughout the advertising industry use body image projection to sell their products because they understood that consumer decision is shaped by social influences [19]. This has affected the youths' mind set about dressing in addition to exposures to social media. For instance, Etodike and Ojiakor [20] linked vulnerability to indecent dressing and sexual risk behaviours to unguided exposures to social media networks Advertisers which are most times seen as models target the youths, and this has contributed in increased awareness of body image among them. Interest in body image also parallels growing public health concerns about weight status, physical inactivity, obesity, eating disorders, and the associated spectrum of health consequences [21]. In response to this increased awareness of body image, youths form mental images of how attractive and body build, they should have based on the advertisers seen as models and also based on health advice and opinions available to them. The influence of this increased awareness on ideal body image as portrayed by advertisers and health opinion metamorphosed in their perspective on how they supposed to dress, how they supposed to look like, what, and how they supposed to feed and engage in physical exercise [22], [21]. If their opinion of their body image corresponds with what they see of their models, there might be a sense of satisfaction about their body image; otherwise, a sense of dissatisfaction could be felt.

Body image satisfaction could be referred to as the extent to which an individual especially a youth likes his/her body appearance according to his or her own assessment and judgment. Youths who have body image satisfaction could be said to have positive body image with a clear, unaltered perception of the shape of their bodies [23]. Generally, these youths feel comfortable in their own 'skin' and are accepting of their natural bodies [24]. On the other hand, body image dissatisfaction results from one's displeasure about one's physical appearance resulting from the mental image one has of an ideal body structure and physical appearance. People who fall under this category seemingly pay undue attention to their physical looks to make up for their imaginary ideal body appearance.

In a cross-cultural study of college-age females' body satisfaction and clothing choice, $\mathrm{Wu}, \mathrm{Xiao}$ and Ashdown [25] found that the participants' clothing choices are greatly affected by their perception and satisfaction level of their own physical body. Along this line, it is noted that low levels of satisfaction in life generally are associated with different types of stress and anxiety can preempt negative changes in behaviour [26]. Similarly, Sontag and Lee In Samreen [19] observed that an individual's perception of their body and physical appearance can affect their clothing pattern. This is to say that body image perception is an essential factor to how a student could dress to school. This is authenticated by the findings of Kodzoman [27] which revealed a psychological undertone of dress choices, resulting from impact of one's perception and interpretation of their physical appearance and body image. Body image dissatisfaction propels individuals to engage in appearance management behaviours which might include dieting and exercising inorder to appear in one's perceived ideal body [28]. A sense of body image dissatisfaction results from negative and poor body image 
which could affect the individual's self-esteem. According to Unachukwu, Ebenebe and Nwosu [18], the youth is primarily concerned with establishing and maintaining self-esteem. These have cognitive impacts on students' task accomplishment and interest in school tasks [29].

Self-esteem literally implies how much value people put on their self-concept. It also implies one's subjective evaluation of self-worth or a person's belief about whether he or she is smart and pretty [30], [31]. Self-esteem encompasses beliefs and emotions such as pride, despair, and shame [17].Literature has revealed that self-esteem of young adults may be affected by peer relationships, media, models etc. [32]. This implies that physical appearance, body image and self-esteem become vital to the overall self-image of young adults which could in turn influence their clothing choices. Rosenberg [33] asserted that individual with high self-esteem is self-accepting of their appearance. The opposite is true of individuals with low self-esteem as they were found to be highly interested in clothing [14]. In his study, Keogan [34] found a correlation between clothing choices and self-esteem. Similarly, Kaur and Dhingra [35] observed a positive interaction between cloth preferences and self-esteem.

Given the challenges and socio-cultural factors which are undeniable with indecent dressing certain question have become pertinent.

1. What is the relationship between body image and indecent dressing among female undergraduates' in universities in Anambra State?

2. What is the relationship between self-esteem and indecent dressing among female undergraduates' in universities in Anambra State?

\section{FRAMEWORK}

This study is anchored on Cognitive dissonance theory propounded by Festinger [36]. This theory sought to explain the linkage between attitudes and behaviour. Dissonance means an inconsistency; that is, inconsistency with expectation, belief, or persons' traits. According to Festinger, human beings constantly strive for mental consistency. Cognitive dissonance refers to any incompatibility that an individual might perceive between two or more attitudes, or between behaviour and attitudes [36]. Festinger [36], construed that any form of inconsistency, conflicting cognition, or dissonance makes people uncomfortable, and as a result of the discomfort, individual will attempt to reduce the dissonance, and hence, the discomfort, until their cognition is in harmony with itself. That is, people try to reduce the discomfort by changing their attitude which could in one way, reflect in their choice of dressing.

Previous literature is consistent that body image and selfesteem have relationship with clothing pattern, preferences, and choices but none was specific on pinning down the choice of clothing to indecent dressing. This study wants to fill the existing gap in literature by exploring body image and selfesteem as predictors of indecent dressing among female undergraduate students in universities in Anambra State.

Given the above theoretical underpinning, the following tentative were made:

1. Body image has significant relationship with indecent dressing among female undergraduate students in universities in Anambra State.
2. Self-esteem has significant relationship with indecent dressing among female undergraduate students in universities in Anambra State.

\section{METHOD}

The study employed correlation research design to explore the relationships between the variables under study. The population of the study comprised all the undergraduate female students in two government-owned universities in Anambra State estimated at 21532. The sample size was 1,250 female undergraduates purposively selected for the study. Students selected were selected based on convenience from different Faculties in the two Universities. Students were permitted to participate once in filling out the questionnaire. Two set of questionnaires validated by experts in Psychology and Measurement and evaluation were used for eliciting responses from the participants. One of the instruments was titled "Body Image and Self-Esteem Questionnaires (BISEQ)".

BISEQ is a 22-item 4-point responses questionnaire adapted from Suzzane Sontang Promixity of Clothing to Self Scale (PCSS). The PCSS is a 39 item questionnaire with 6 clusters. The researcher adapted the clusters that measure selfesteem $(8$ items $=$ evaluative and 7 items $=$ affective process - total of 15 items) and body image (7 items) respectively, for this study.

A 10-item, 4-pointresearcher constructed instrument titled "Indecent Dressing Scale (IDS)" was used in eliciting responses from the participants on their ability to put on indecent dressing to school. The reliability of the instruments was obtained using Cronbach Alpha method. After distributing the questionnaires to 45 female undergraduates in government-owned university in Imo State, the analysis yielded an alpha coefficient of 0.71 and 0.69 for BISEQ and IDS respectively. This showed that the instruments were reliable for this study. The data collected were analyzed using Pearson Product Moment Correlation for answering the research questions and Regression Analysis was employed in testing the hypotheses.

\section{RESULT}

TABLE I: RELATIONSHIP BETWEEN BODY IMAGE AND INDECENT DRESSING OF UNDERGRADUATE FEMALE STUDENTS IN UNIVERSITIES IN ANAMBRA STATE

\begin{tabular}{ccc}
\multicolumn{3}{c}{ UNIVERSITIES IN ANAMBRA STATE } \\
\hline $\mathrm{N}$ & $\begin{array}{c}\text { Correlation } \\
\text { coefficient (r) }\end{array}$ & Remark \\
\hline 1,250 & 0.690 & High correlation \\
\hline
\end{tabular}

Data in Table I shows that the correlation coefficient between body image and indecent dressing among undergraduates is $r=0.690(p \leq 0.05)$. This reveals that there is a high and positive relationship between body image and indecent dressing among undergraduate students in Nnamdi Azikiwe University.

TABLE II: RELATIONSHIP BETWEEN SELF-ESTEEM AND INDECENT DRESSING OF UNDERGRADUATES IN UNIVERSITIES IN ANAMBRA STATE

\begin{tabular}{ccc}
$\mathrm{N}$ & $\begin{array}{c}\text { Correlation } \\
\text { coefficient }(\mathrm{r})\end{array}$ & Remark \\
\hline 1,250 & 0.704 & High correlation \\
\hline
\end{tabular}


Data in Table II shows that the correlation coefficient between body image and indecent dressing among undergraduates is $r=0.704(p \leq 0.05)$. This reveals that there is a high and positive relationship between self-esteem and indecent dressing among undergraduates in Nnamdi Azikiwe University.

TABLE III: REGRESSION ANALYSIS OF BODY IMAGE AND INDECENT DRESSING OF UNDERGRADUATE STUDENTS IN UNIVERSITIES IN ANAMBRA STATE

\begin{tabular}{|c|c|c|c|c|c|c|c|}
\hline Model & SS & $\begin{array}{l}\mathrm{D} \\
\mathrm{f}\end{array}$ & MS & $\mathrm{F}$ & $\mathrm{R}^{2}$ & $\beta$ & Sig \\
\hline Regressio & 8966.97 & & 2024 & & & & \\
\hline $\mathrm{n}$ & 9022.86 & 1 & 11365.4 & 70 & 0.47 & 0.69 & .00 \\
\hline Residual & 17988.8 & & 2 & 2 & 7 & 0 & 0 \\
\hline Total & 9 & & 1021 & & & & \\
\hline
\end{tabular}

Data in Table III show that an F-ratio of 1136.702 with associated exact probability value of 0.000 was obtained. This exact probability value of 0.00 was less than 0.05 level of significance and therefore, found to be significant. Thus, the null hypothesis was not accepted. Inference drawn was, therefore, that there was a significant relationship between body image and indecent dressing among undergraduates in Nnamdi Azikiwe University.

TABLE IV: REGRESSION ANALYSIS OF SELF-ESTEEM AND INDECENT DRESSING OF UNDERGRADUATE STUDENTS IN UNIVERSITIES IN ANAMBRA STATE

\begin{tabular}{cccccccc}
\hline Model & SS & Df & MS & F & $\mathrm{R}^{2}$ & $\beta$ & Sig \\
\hline Regression & 9242.155 & & 9242 & & & & \\
Residual & 9413.586 & 1 & 12487.543 & 1225.3 & 0.477 & 0.704 & .000 \\
Total & 18655.741 & & 1249 & & & & \\
\hline
\end{tabular}

Predictors: (constant), self-esteem: Dependent variable: Indecent Dressing.

Data in Table IV show that an F-ratio of 1225.273 with associated exact probability value of 0.000 was obtained. This exact probability value of 0.00 was less than 0.05 level of significance and therefore, found to be significant. Thus, the null hypothesis was not accepted. Inference drawn was, therefore, that there was a significant relationship between self-esteem and indecent dressing among undergraduate female students in Nnamdi Azikiwe University.

\section{DISCUSSION}

The finding of this study revealed that body image has a positive and significant relationship with indecent dressing among undergraduate female students of Nnamdi Azikiwe University. This corroborates with $\mathrm{Wu}, \mathrm{Xiao}$, and Ashdown [25] who found that the participants' clothing choices are greatly affected by their perception and satisfaction level of their own physical body. This finding is authenticated by the findings of Kodzoman [27] which revealed a psychological undertone of dress choices, resulting from impact of one's perception and interpretation of their physical appearance and body image. This could be explained by the vicarious learning young adults imbibe from dressing styles of the celebrities they hold as role models. They dress skimpily in order to appear like their models and also in a bid to impress and show off their perceived beautiful body, they dress to slay.

Considering that students' indecent dressing behaviour are forms of social maladjustments which may be injurious to normal developmental life of the students, there is need therefore to extend the search for the covariables to religious lifestyle and assertiveness competence of students under prevailing social pressures such as peer influence. For instance, there is association among religiosity, assertiveness competence and social maladjustment [37].

The study also revealed that self-esteem has a positive and significant relationship with indecent dressing among female undergraduate students. The findings of this study agree with Keogan [34] who found a correlation between clothing choices and self-esteem. Similarly, it aligns with Kaur and Dhingra [35] that there is a positive interaction between cloth preferences and self-esteem. This could be explained because self-esteem boosts self-perception which can in turn influence one's choices of clothing pattern. Low self-esteem could make a female undergraduate student to be particularly interested in clothing, perhaps, to appear accepting in her own judgment.

\section{IMPLICATION OF STUDY FINDINGS}

Students' self-perception of themselves as regards the psycho-social influence of the society may influence behaviour especially geared repairing such ill-perception and disillusions to an extent that they may become injurious both the student, people around and the society at large. There are known dangers of indecent dressing including attraction of unhealthy persons of the opposite sex. In some instance, indecent dressing may attract friends with questionable characters due to the allure of the dressing code and an expected deviance. All these further imply that the student may become seriously distracted with studies and central focus of studentship.

\section{LIMITATIONS}

Socialization especially at the tertiary education level is a powerful influencing factor of students' behaviour especially as regards peer influence. This may influence the dressing behaviour of students and hence the outcomes of the study. However, this variable was controlled by measuring only the self-perceived beahiour of respondents during the survey. Again, the influence of peers was also seen as constant present among the study population and hence will not significantly affect the result considering that the influencers are themselves influenced by internal factors such as selfesteem and perception of body image.

\section{RECOMMENDATIONS}

There is need to ascertain the motives of the students involved in indecent dressing in view of understanding it more. There is also the need to ascertain of environemtal influencers on students' dressing behaviour such as comparison between environments. More studies should also attempt evaluating the impacts of FOMO (Fear of Missing Out) on students' dressing behaviour in addition to already existing literature. There recommended studies will increase the understanding of students' indecent dressing behaviour and factors associated with it. 


\section{CONCLUSION}

Having confirmed positive and significant relationship between body image and indecent dressing; it follows that students' negative perception of their looks and body features such as their height, shape of waist, bottom, or breast or other masculine or feminine features have compelling influence on indecent dressing. Also, how students carry themselves and feel good about their selves equally influences dressing attitudes. Thus, how student perceive their physical body features and their psychological values are critical influencers on dressing behaviour and hence should be the concern of parents, teachers, churches, and civil societies. Thus, the study concludes that body image and self-esteem being positive and significant influencers of dressing behaviour should be of interest to all stakeholders even outside the learning environment.

\section{REFERENCES}

[1] Omoni, G. \& Onoyase, A. (2019). Inappropriate sexual behaviour as perceived by students in the institute of education, Delata State University, Abraka: Implications for Counselling. International Journal of Psychological Studies 11(2), 54-61. https://doi.org/10.5539/ ijps.v11n2p54.

[2] Anadi, C. C.; Egbka, P. N. \& Anierobi, E.I. (2011). Indecent dressing among female undergraduates students in Nnamdi Azikiwe University, Awka: Types, sustaining factors and implications for rebranding Nigeria Agenda. Journal of Sociology of Education 5(1), 1-12. https://scholar.google.com/citations?user=exfhAcoAAAAJ\&hl=en.

[3] Anierobi, E.I., Etodike, C.E., Nwogbo, V.N., Okeke, N.U., \&Nwikpo, M.N. (2021). Evaluating Sexual Harassment against Female Workers in Higher Institutions in Anambra State, Nigeria. International Journal of Academic Research in Business and Social Sciences, 11(2), 265$278 . \quad \mathrm{http}: / / d x$. doi.org/10.6007/IJARBSS/v11-i2/8687 DOI:10.6007/IJARBSS/v 11-i2/8687.

[4] Birhan, W. (2019). A review on normative and other factors contributing to Africa's adolescent development crises. Academic Journals 9(1), 1-9. https://doi:10.5897/PPR2018. 0161.

[5] Erhunse, C. (2019). Indecent dressing among undergraduate students in Nigeria: Counsels for solving the problem. GRIN e-Books. https://www.grin.com/document/507384.

[6] Akpan, G. E. (2018). Effects of indecent dressing on undergraduate students of university of Uyo, Uyo, Nigeria. International Journal of Physical Education, Sports and Health 5(2), 359-361.

[7] Ezeh, L.N \&Etodike, C.E. (2016). Corruption in Nigeria organizations: Theories \& implications. In Proceedings of Annual Scientific Conference of Nigeria Psychological Association (NPA), held at Nnamdi Azikiwe University Awka, Nigeria, 11th - 14th Oct. 2016.

[8] Etodike, C.E., Ike, P.R. \&Chukwura, E.N. (2017). Assertiveness training: academic performance and self-esteem among college students in selected rural areas. International Journal for Psychotherapy in Africa 2(1), 7-13.

[9] Ike, P.R., Etodike, C.E. \& Edwards, L.N (2017). Religiosity, And Social Mal-Adjustment as Correlates of Assertiveness Competence among Undergraduates. International Journal for Psychotherapy in Africa 2(1), 149-156.

[10] Olorunda, S. (2018). Indecency dressing among youths in southwestern Nigeria.

[11] Osagiobare, E. O.; Ekwukoma, V.\& Ekomaru, C. I. (2015). Forms of indecent dressing among university students in north central geopolitical zone. Sokoto Educational Review 16 (1), 94-101 www.sokedureview.org.

[12] Bua, F. T. \&Tsav, S. A. (2014). Impact of indecent dressing on the academic performance of students of college of education in Kastina Ala in Benue State in Nigeria. International Journal of Innovative Education Research 2 (1), 26-36.

[13] Ojogbane, V. J.; Amonjenu, A. \& Husseini, A. O. (2020).Impact of dress code on the academic performance of undergraduate students in the federal university of agriculture, Markurdi, Benue State, Nigeria. European Journal of Education Studies 7(6), 171-183.

[14] Kwanuba Yohanna, L. K. \&Sababa, J. F. (2020). Students' perception of indecent dressing in Adamawa citadel of higher learning. International Journal of Engineering and Science 10(10), 44-56.

[15] Apuke, D. O. (2017). The influence of home-movies on the dressing pattern of students: A study in a Nigerian public university. CrossCultural Communication 3(1), 31-41.

[16] Salela, G. R. \&Mawuli, Q. (2013). The impact of indecent dressing on the academic performance of students in tertiary institutions, A case study of Ho Polytechnic in Ghana. Journal of Education and Practice 4(18) $165-172$

[17] Alebachew, F. \& Ashagrie, M. (2017). Body image concept analysis of youth and adolescent. American Journal of Biomedical and Life Sciences 5(6), 130-134 https://doi.10.11648/j.ajbls.20170506.14.

[18] Unachukwu, G. C.; Ebenebe, R. C. \&Nwosu, K. C. (2019). Developmental psychology and education (3rd ed.). Enugu, Nigeria: Agatha Series Pub. Ltd.

[19] Samreen, N. (2014). Proximity of clothing to self-concept Understanding differences across the demographics in Pakistan. European Journal of Business and Management 6 (18), 95-106. www.iiste.org.

[20] Etodike, C.E \& Ojiakor, I.C. (2018). Social Media Networks and associated vulnerability to sexual risk behaviours among adolescents. European Journal of Open Education and E-Learning Studies 3(1), 6678. http://www.oapub.or/eduDOI:10.5281/zenodo.12525 40.

[21] Voelker, D. K., Reel, J. J., \& Greenleaf, C. (2015). Weight status and body image perceptions in adolescents: Current perspectives. Adolescents Health Medicine and Therapeutics, 6, 149-158.

[22] Javellana, G. (2014). Influence of media on body image satisfaction among adolescents. Asia Pacific Journal of Education, Arts and Sciences, 1 (1), 106-117.

[23] Ballweg, B. (2014). Combating eating disorders by addressing body image issues in schools. A Capstone Project submitted in Partial Fulfilment of the requirements for the Masters of Science Degree in Counselling Education, Winona University. Retrieved from https://www.counseling-and-body-image-spring-2014-capstonepdf

[24] National Eating Disorders Association (2012). What is body image? Retrieved from https://www.nationaleatingdisorders.org/what-is-bodyimage.

[25] Wu, Y.; Xiao, P. \& Ashdown, S. P. (2018). A cross-cultural study of college-age females' body satisfaction and clothing choices. Journal of Textile Engineering and Fashion Technology 4 (2), 174-179. https://doi:10.15406/jteft.2018.04.00137.

[26] Etodike, C.E., Ezeh, L.N. \& Chukwura, E.N. (2017). Life Satisfaction and Perceived Social Support as Predictors of Retirement Stress among Nigeria Public Service Retirees. International Journal of Current Advanced Research, 6(2), 2301-2311.www.journalicar.org.

[27] Kodzoman, D. (2019). The psychology of clothing: Meaning of colors, body image and gender expression in fashion. Textile Leather Review 2(2), 90-103 https://doi.10.31881/TLR.2019.22.

[28] Kim, J. \& Kang, J. M. (2015). Investigation of the role of proximity of clothing to self anticipating risky appearance management behaviours. International Journal of Fashion Design, Technology and Education 8(3), 235-242 https://doi.org/10.1080/17543266.2015.1074292.

[29] Etodike, C. E., Nwangwu, N. I., Nnaebue, C. I., \& Anierobi, E. I. (2020). Effect of Time Management and Monetary Rewards on Cognitive Task Accomplishment among Students of Nnamdi Azikiwe Secondary School, Awka, Nigeria. Canadian Social Science, 16(8), 29 35. http://www.cscanada.net/index.php/css/article/view/11836 DOI http://dx.doi.org /10.3968/11836.

[30] Anierobi, E. I.; Nwikpo, M. N.; Okeke, A. N, \& Unachukwu, G. C. (2018). Peer influence and self-esteem as correlates of secondary school students' attitude towards examination malpractice in Anambra State. The Educational Psychologist 12 (1), 48-62.

[31] Uslu, M. (2013). Relationship between degrees of self-esteem and peer pressure in high school adolescents. International Journal of Academic Research, 5(3), 117-122.

[32] Kalyani, K. (2014). Correlates of personality and self-esteem among youth. Journal of Humanities and Social Science, 19(2), 22-26.

[33] Rosenberg, M. (1989). Society and the adolescent self-image. Connecticut: Wesleyan University Press.

[34] Keogan, K. (2013). The relationship between clothing preferences, self-concept and self-esteem. https://resource.dbs.ie/bitstream/ handle/10788/1620/ba_keogan_k_2013.pdf? Sequence $=1$.

[35] Kaur, R. \& Dhingra, R. (2017). Clothing interest and its relationship with teens in Jammu City. Imperial Journal of Interdisciplinary $\begin{array}{llll}\text { Research } & 3 & \text { (3), 135-140 http://www.onlinejournal }\end{array}$ in/IJIRV3I3/021.pdf.

[36] Festinger, L. (1957). A Theory of Cognitive Dissonance. Evanston, IL Row Press.

[37] Ike, P.R., Etodike, C.E. \& Edwards, L.N (2017). Religiosity, And Social Mal-Adjustment as Correlates of Assertiveness Competence among Undergraduates. International Journal for Psychotherapy in Africa 2(1), 149-156. 


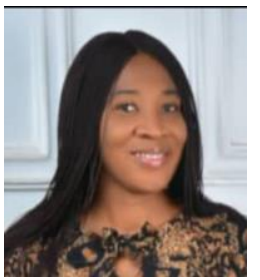

Ifeoma Elizabeth Anierobi, $\mathrm{PhD}$, was born in Awka, Anambra State, Nigeria. Ifeoma obtained her Bachelor's Degree (psychology) in 2002, Master's Degree (educational psychology) in 2016, and Doctorate Degree (educational psychology) all from Nnamdi Azikiwe University Awka (NAU).

She is a lecturer in the Department of Educational Foundations, NAU, Awka and has served in many administrative capacities as a former Senior Assistant Registrar in same University. She is a member of her professional association, Nigeria Council of Educational Psychologists (NCEP) and also a member of Teachers Registration Council of Nigeria (TRCN). Her areas of interest include psychology of learning, adolescents' behaviour and special education.

Dr. Anierobi has authored and co-authored many articles published in both national and international journals. Presently, she is a member of the International Conference Committee of the Faculty of Education, NAU, Awka.

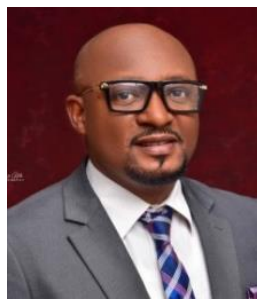

Chukwuemeka Nelson Etodike, $\mathrm{PhD}$ is an author and critical analyst. Chukwuemeka obtained his Doctorate Degree in Industrial/Organizational Psychology from Nnamdi Azikiwe University Awka, Nigeria. His research interest spans across human resource management and policy, political antecedents, and psycho-sociological underpinnings of the human society with emphasis on organizational climates, workplace attitudes and job outcomes.He has over 50 publications in Int'l and local journals; and conference proceedings.

Dr. Etodike is the principal research consultant at Heritage Research Gallery \& Mgt Consult Ltd Awka, and a recipient of NeurIPS/ML4D Research Grant (Canada) and ACM-SIGCHI Gary Marsden Students' Research Grant (USA), and TetFund-IBR Research Grant (Nigeria).

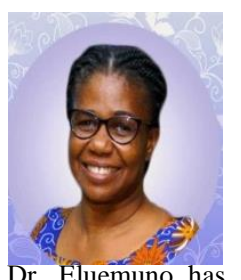

Azukaego Eluemuno holds a $\mathrm{PhD}$ \&M.Ed in Educational Psychology from the University of Lagos and a B.A in English Education from the University of Nigeria, Nsukka.

She has many years of experience as a Lecturer in Educational Psychology. She has also attended lots of Conferences published articles in both International and Local reputable Journals.

Dr. Eluemuno has also written chapters in the book; Adolescence: Psychological Perspective. She is currently a Lecturer in the Department of Educational Foundations, Faculty of Education Nnamdi Azikiwe University Awka.

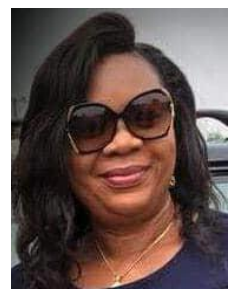

Nneka Mary Nwikpo, PhD. currently works at the Department of Educational Foundations, Nnamdi Azikiwe University, Awka, Nigeria. She holds a $\mathrm{PhD}$ in Educational Psychology from Nnamdi Azikiwe University, Awka and a B.A in Igbo Linguistics from the University of Lagos. She was a veteran high school teacher and Media presenter of repute at African Independent Television (AIT), Lagos, Nigeria. She has attended many academic conferences and has published numerous articles both in reputable Nigerian and international journals.

Dr. Nwikpo is a member of Nigerian Council of Educational Psychologists and Nigerian Psychological Association. 